(4)

Seri Sumbangan Pemikiran Psikologi Untuk Bangsa 1

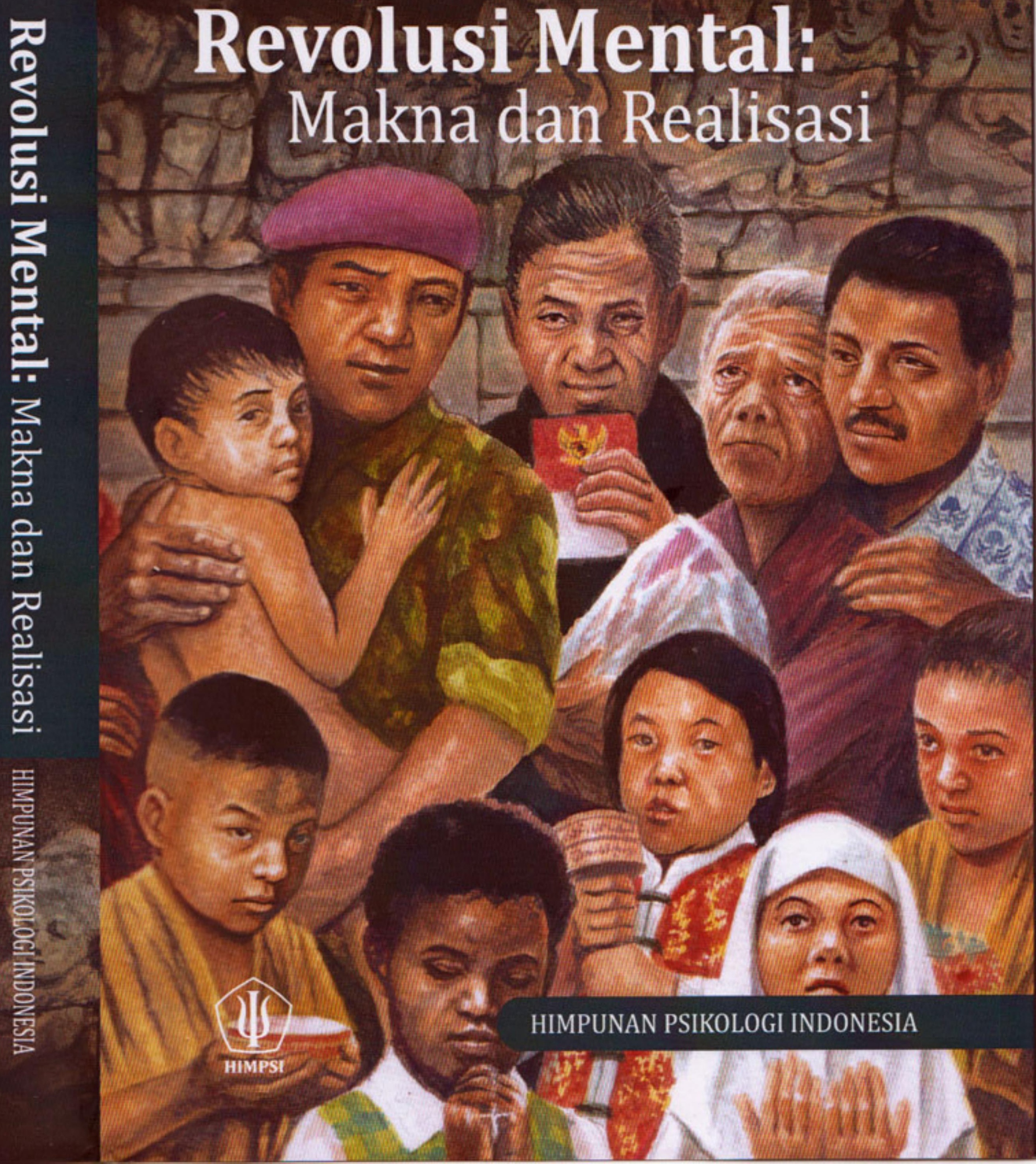


Menjadi bagian dari sebuah revolusi mental yang sesungguhnya merupakan tantangan terbesar dari kepengurusan Himpunan Psikologi Indonesia (HIMPSI) periode 2014-2018. Revolusi mental melibatkan refleksi tajam untuk kembali ke nilai dasar karakter dan mentalitas bangsa yang dalam pelaksanaannya dapat dilihat pada komitmen dan kesungguhan dalam cara pandang, sikap dan perilaku dalam menghadapi suatu situasi.

Menyadari kemajemukan di segala bidang kehidupan dan sebagai organisasi profesi yang anggotanya secara nyata bergelut dengan kemajemukan tersebut, maka dibutuhkan kemampuan untuk menganalisa situasi dan kemudian menjabarkan revolusi mental tersebut dalam berbagai aspek kehidupan. Kemampuan ini dilatih dengan mengalami sendiri atau belajar dari pengalaman orang lain.

ari 2015 dani

Buku Revolusi Mental: Makna dan Realisasi adalah seri pertama dari rencana penerbitan reguler tahunan dalam kepengurusan HIMPSI. Seri sumbangan pemikiran Psikologi untuk bangsa Indonesia ini berisi kompilasi gagasan/ide/pemikiran/opini dari komunitas Psikologi terhadap permasalahan-permasalahan bangsa. Tulisan yang tersaji dalam buku ini mencoba untuk menyelaraskan konsep dan teori Psikologi berkaitan dengan situasi/persoalan serta implementasi konkrit tentang revolusi mental yang bisa dan sudah dijalankan.

Sungguh membanggakan bahwa penerbitan perdana ini mampu mengkompilasi 33 tulisan yang telah diseleksi dan melalui proses evaluasi untuk memastikan tulisan yang mampu menginspirasi pembacanya. Penghargaan saya sampaikan pada sejawat yang sudah mengirimkan tulisan, tim editor yang luar biasa dari Kompartemen 4 dan juga bagi semua pihak yang ikut berperan dalam penerbitan buku ini. Harapan saya agar kontribusi HIMPSI 
lewat tulisan ini mampu menstimulasi terselenggaranya diskusi yang bermanfat mendorong munculnya pembawa perubahan 'agent of change' dalam kemajemukan be kita tercinta. Revolusi mental bermula dari diri sendiri dan dari membaca tulisan dibu ini.

HIMPSI berkarya untuk bangsa

\section{Dr. Seger Handoyo, Psikolog}

Ketua Umum

Mei 2015 


\section{DAFTAR ISI}

Pengantar TIM Editor

\section{BAGIAN I "Membaca" Revolusi Mental}

1. Revolusi Mental Melalui Pembangunan Sosial

Bagus Takwin.

2. Memaknai Konsep Revolusi Mental Jokowi dalam Pendekatan Psikologi Hamdi Muluk.

3. Revolusi Mental dalam Pembangunan Karakter Bangsa Indonesia: Suatu Tinjauan Psikologi

Ngurah Sumitra

4. Desain (R)evolusi Mental dalam Pembangunan Karakter Bangsa Ifa Hanifah Misbach

\section{BAgIAN II Dunia Pendidikan dan Keluarga}

5. Karakter sebagai Hasil Pendidikan:Yang Personal dan yang Sosial Nani Nurrachman

6. Menumbuh-kembangkan Generasi Berintegritas Moral

Irwanto

7. Diperlukan: Revolusi Mental dalam Pembangunan Karakter Bangsa Indonesia

Solita Sarwono 
8. Revolusi Mental: Membangun Karakter Bangsa Melalui Penerapan Nilai

\section{Religius}

Tiwin Herman.

9. Pendidikan Karakter: Revolusi Mental dalam Bidang Pendidikan

Sukma Rahastri Kanthi dan Ike Herdiana

10. Lupakanlah Student Centered Learning

Juneman Abraham 


\title{
Lupakanlah Student Centered Learning
}

\author{
Juneman Abraham
}

Model pembelajaran di Indonesia dan di dunia telah mengalami beberapa kali revisi. Dengan berbagai varian dan labelnya, pada dasarnya sejarah dunia pendidikan telah melaksanakan dua model besar pembelajaran, yakni pembelajaran berpusat pada guru (teacher-centered learning; TCL) dan pembelajaran berpusat pada siswa (student-centered learning; SCL).

Pada TCL, penguasa pengetahuan adalah guru. Hal ini sangat dimungkinkan terjadi pada masa di mana atmosfer "kegelapan" menguasai sekolah-sekolah. Pada saat itu, pengetahuan dan ilmu terlebih yang mutakhir sangat sulit diperoleh. Dosen-dosen dan guru-guru dikirim ke luar negeri untuk menimba ilmu dari para mahaguru maupun dari perpustakaan yang diibaratkan "oase" pengetahuan. Saat tiba di tanah air, tidak mengherankan bahwa guru bak "dewa ilmu". Berkat kemurahan hati para gurulah, para siswa memperoleh "pencerahan". Oleh karena para siswa tidak memiliki alternatif sumber ilmu yang memadai, maka hal-hal yang disampaikan oleh guru hanya dapat diterima, ditelan apa adanya, tanpa dapat diperdebatkan. Mengapa? Sebab perdebatan yang baik membutuhkan referensi sebagai alasnya. Sementara referensi yang dimiliki siswa tidak mungkin ada yang lebih maju daripada yang dimiliki oleh guru (pada masa itu). Dengan perkataan lain, siswa sangat bergantung pada guru. Kita sulit bersikap kritis terhadap seseorang atau sesuatu di mana kita total menggantungkan diri padanya.

Guru yang mulanya memiliki otoritas akademik, entah melalui "efek halo", kemudian juga menjadi otoritas moral. Guru adalah sang kebenaran. Oleh karenanya, segala bentuk disiplin yang diterapkan oleh guru (termasuk hukuman fisik) dipandang sebagai proses pemurnian bagi siswa untuk menjadi "benar" dan "bermoral". "Sabda" guru adalah sabda yang keramat. Yang ideal bagi siswa adalah mencatat, mengingatnya, dan mengulangi atau menerapkannya secara persis. Para Orang tua siswa pun umumnya memaklumi hal ini. 
Abraham, J. (2015). Lupakanlah student centered learning. In: H. Panggabean, A. Supratiknya, \& J. S. A. Utama (Eds.), Revolusi mental: Makna dan realisasi (pp. 129-136). Jakarta: Himpunan Psikologi Indonesia.

10

\title{
Lupakanlah Student Centered Learning
}

\author{
Juneman Abraham
}

Model pembelajaran di Indonesia dan di dunia telah mengalami beberapa kali revisi. Dengan berbagai varian dan labelnya, pada dasarnya sejarah dunia pendidikan telah melaksanakan dua model besar pembelajaran, yakni pembelajaran berpusat pada guru (teacher-centered learning; TCL) dan pembelajaran berpusat pada siswa (studentcentered learning; SCL).

Pada TCL, penguasa pengetahuan adalah guru. Hal ini sangat dimungkinkan terjadi pada masa di mana atmosfer "kegelapan" menguasai sekolah-sekolah. Pada saat itu, pengetahuan dan ilmu-terlebih yang mutakhir-sangat sulit diperoleh. Dosen-dosen dan guru-guru dikirim ke luar negeri untuk menimba ilmu dari para mahaguru maupun dari perpustakaan yang diibaratkan "oase" pengetahuan. Saat tiba di tanah air, tidak mengherankan bahwa guru bak "dewa ilmu". Berkat kemurahan hati para gurulah, para siswa memperoleh "pencerahan". Oleh karena para siswa tidak memiliki alternatif sumber ilmu yang memadai, maka hal-hal yang disampaikan oleh guru hanya dapat diterima, ditelan apa adanya, tanpa dapat diperdebatkan. Mengapa? Sebab perdebatan yang baik membutuhkan referensi sebagai alasnya. Sementara referensi yang dimiliki siswa tidak mungkin ada yang lebih maju daripada yang dimiliki oleh guru (pada masa itu). Dengan perkataan lain, siswa sangat bergantung pada guru. Kita sulit bersikap kritis terhadap seseorang atau sesuatu di mana kita total menggantungkan diri padanya.

Guru yang mulanya memiliki otoritas akademik, entah melalui "efek halo", kemudian juga menjadi otoritas moral. Guru adalah sang kebenaran. Oleh karenanya, segala bentuk disiplin yang diterapkan oleh guru (termasuk hukuman fisik) dipandang sebagai proses pemurnian bagi siswa untuk menjadi "benar" dan "bermoral". "Sabda" guru adalah sabda yang keramat. Yang ideal bagi siswa adalah mencatat, mengingatnya, dan mengulangi atau menerapkannya secara persis. Para orangtua siswa pun umumnya 
Abraham, J. (2015). Lupakanlah student centered learning. In: H. Panggabean, A. Supratiknya, \& J. S. A. Utama (Eds.), Revolusi mental: Makna dan realisasi (pp. 129-136). Jakarta: Himpunan Psikologi Indonesia.

memaklumi hal ini. Guru didukung penuh oleh para orangtua pada hampir apapun yang dilakukan oleh guru.

"Kemauan guru" menjadi penentu segala-galanya dalam proses pembelajaran. Aspirasi siswa teredam. Siswa menjadi semacam angka atau statistik. Sukses siswa, sukses kelas, semata-mata memuaskan pikiran dan hasrat guru itu. Oleh karena didefinisikan oleh guru, logis jika "sukses" itu menjadi kurang (atau, tidak) bermakna bagi siswa!

Model pembelajaran yang demikian memang tidak mengundang dinamika di kelas. Suasana pembelajaran menjadi kaku, dingin, dan, kata anak sekarang, "garing!". Pembelajaran yang demikian memang bisa "makan hati" lagi "menyakitkan" (di mata siswa).

Namun demikian, tunggu dulu... "Aneh tapi nyata"-nya, siswa banyak yang memuji kebesaran, kearifan, dan kebestarian gurunya setelah lulus. Jasa guru diakui tiada tara yang menjadikannya bisa berkarya dan "bisa jadi orang” seperti sekarang ini. Cek saja memoar orang-orang ternama dan begawan di bidangnya. Anda hampir pasti akan menemukan jasa guru di dalamnya. Hal ini mengingatkan kita kepada film-film Shaolin.

Murid awalnya tidak mengerti sama sekali apa yang diperintahkan gurunya. Murid ingin belajar Kung $\mathrm{Fu}$ malah disuruh guru menimba dan mengangkat air. Umumnya setelah murid menyelesaikan tahapan pembelajarannya, lalu "turun gunung" dan menghadapi lawan-lawannya di lapangan, murid teringat episode-episode pembelajaran oleh gurunya (kadang sambil menangis!). Murid lalu baru benar-benar merasakan manfaat dari perintah-perintah yang awalnya seperti tidak relevan dan tanpa makna tersebut. Biasanya pada saat itu, guru telah tiada. Murid mengunjungi makam guru dan memberikan penghormatan tanda bakti.

Bertahun-tahun kita "dikuasai” oleh kultur TCL. Ada yang puas (tentu saja terutama para guru). Banyak yang tidak puas, dan disuarakan oleh filosof dan pakar pembelajaran. TCL dipandang tidak "manusiawi”. Manusia diklaim seperti "gelas" (yang dituangi air dari guru sebagai "kendi"), seperti "robot" (yang menjadi objek manipulasi guru untuk dibentuk sebagaimana yang guru inginkan). Datanglah arus pragmatisme, konstruktivisme, humanisme, dan konstruksionisme, yang digunakan untuk menggugat dan menggeser sama sekali TCL. Inilah era SCL (student-centered learning)! 
Abraham, J. (2015). Lupakanlah student centered learning. In: H. Panggabean, A. Supratiknya, \& J. S. A. Utama (Eds.), Revolusi mental: Makna dan realisasi (pp. 129-136). Jakarta: Himpunan Psikologi Indonesia.

\section{Student-centered Learning}

Imbas arus pragmatisme mengatakan bahwa pembelajaran mesti menjawab kebutuhan konkret siswa dalam hidup kesehariannya. Oleh karenanya, baik metode maupun isi pembelajaran yang digunakan oleh guru perlu dievaluasi terus-menerus seiring dengan kemampuan dan "kemauan" atau aspirasi siswa (demokratis!).

Argumennya, jika pembelajaran dikemas sesuai dengan kapasitas dan keinginan siswa, maka iklim pembelajaran menjadi menyenangkan, maka siswa akan gemar belajar (tanpa disuruh sekalipun!), maka materi yang disampaikan lebih mudah mendarahdaging dan "menubuh" (embodied).

Imbas arus konstruktivisme mengatakan bahwa pembelajaran mesti melibatkan penafsiran yang dibangun oleh si pembelajar sendiri berdasarkan gagasan dan pengalaman yang diterimanya. Jadi TCL keliru karena memberikan "barang (pengetahuan) jadi", apalagi barang tersebut "barang impor" (dari luar negeri) yang belum tentu sesuai dengan situasi siswa di rumah, di tetangga, di RT, dan di tanah airnya.

Imbas arus humanisme mengatakan bahwa pembelajaran mesti memperlakukan manusia sebagai manusia, yang sedang berproses memanusiakan dirinya. Artinya, pendidikan mesti mengarah pada pertumbuhan manusia sebagai makhluk yang mampu mengaktualisasikan segenap potensi dirinya secara otonom.

Imbas arus konstruksionisme mengatakan bahwa pembelajaran di ruang kelas merupakan kontributor penyusun realita sosial. Oleh karenanya, pembelajaran mesti diarahkan untuk mengubah kondisi sosial menuju kebaikan bersama (common good).

Siswa mesti memiliki kepekaan dan merasa gelisah apabila pengalaman dan observasinya berjumpa dengan ketidakadilan dalam kehidupan sosialnya. Siswa diajak untuk membangun (dan memelihara!) kesadaran kritis bahwa tindakannya tidaklah hanya dipengaruhi (secara pasif) oleh situasi sosial, melainkan juga mempengaruhi situasi itu.

Salah satu implikasi dari arus filosofis tersebut adalah bahwa intervensi dalam kehidupan sosial seringkali membutuhkan tindakan bersama dari para pelajar berdasarkan pengetahuan yang dibangunnya. Siswa ingin (dan dapat) mengubah kenyataan sosial. 
Abraham, J. (2015). Lupakanlah student centered learning. In: H. Panggabean, A. Supratiknya, \& J. S. A. Utama (Eds.), Revolusi mental: Makna dan realisasi (pp. 129-136). Jakarta: Himpunan Psikologi Indonesia.

Berdasarkan arus-arus filosofis tersebut, salah satu konsekuensi terpenting dari

SCL adalah pembelajaran berdiferensiasi (differentiated instruction). Dalam pembelajaran ini, dimensi-dimensi pembelajaran disesuaikan dengan dimensi-dimensi situasi dari tiap-tiap siswa. Hal ini mengingatkan kita kepada pendekatan berpusat pada pelanggan (customer-centric) yang dikenal dalam dunia pemasaran. Guna menarik pelanggan, kegiatan sentral yang perlu dilakukan adalah pemrofilan pelanggan. Hal yang perlu diprofilkan adalah keseluruhan aspek dari pelanggan itu sendiri, baik fisik, psikologis, sosial, kalau perlu, spiritual. "Pelanggan" dalam pendidikan adalah siswa. Berdasarkan profil menyeluruh dari siswa itulah, pembelajaran dilakukan dan dievaluasi.

Guru merupakan fasilitator yang merangsang seluruh kemungkinan yang ada pada siswa (sebagaimana didefinisikan oleh siswa itu sendiri) sehingga profilnya menjadi semakin baik dan berdaya dari waktu ke waktu.

\section{Keterbatasan SCL}

Model pembelajaran SCL bukanlah tanpa kelemahan. Sejumlah kelemahan telah cukup nyata seperti: tidak semua siswa dapat efisien dan efektif belajar/bekerja dalam kelompok (yang sudah menjadi "tradisi" SCL); sumberdaya pengajar yang benar-benar memahami filosofi dari SCL dan sungguh-sungguh mau mengeluarkan upaya ekstra untuk mempraktikannya secara penuh masih sangat terbatas; sebagian siswa sesungguhnya merasa "tersesat dan kehilangan arah" tanpa kejelasan panduan, peta jalan, klarifikasi, dan penyimpulan dari guru; bahkan (yang lebih menyedihkan!) guru malah minim persiapan dan kurang tergerak untuk terus-menerus mendalami keilmuannya (padahal sudah disertifikasi!). Sebagian siswa malah mengidentikkan SCL dengan " $A h$ kami paling disuruh presentasi dan tugas-tugas kelompok melulu oleh guru! Enak ya jadi guru zaman sekarang!'”.

Di atas semua itu, penulis melihat adanya gejala-gejala mendasar yang seyogianya patut kita perhatikan. Penulis mencermati bahwa belakangan survei sistematis maupun tulisan pribadi yang bertemakan "karakteristik guru yang disukai siswa" cukup marak. Sejumlah kualitas yang cukup konsisten muncul adalah humoris, memotivasi, bersahabat (friendly), memberikan teladan, perhatian, tidak mudah marah, sampai dengan dermawan (dengan berbagai interpretasinya; salah satunya adalah memberikan kisi-kisi 
Abraham, J. (2015). Lupakanlah student centered learning. In: H. Panggabean, A. Supratiknya, \& J. S. A. Utama (Eds.), Revolusi mental: Makna dan realisasi (pp. 129-136). Jakarta: Himpunan Psikologi Indonesia.

soal ujian!). Guru-guru dituntut untuk memenuhi sejumlah kualitas tersebut. Namun demikian, tidak banyak survei sistematis yang menangkap "karakteristik siswa yang disukai guru" dan meminta siswa untuk sedikitnya memahami dan mencoba mengambil perspective taking dari sisi guru. Gejala non-resiprokal ini patut kita cermati. Padahal, jika kita sepakat bahwa guru mesti mampu mengapresiasi kondisi siswa yang beragam, maka kita juga mesti sepakat bahwa siswa pun perlu diajak untuk belajar mengapresiasi kondisi guru yang beragam. Kegagalan memahami hal ini akan berakibat "mutiara dari sang guru" tidak akan keluar karena tertutup kabut ekspektasi siswa melulu. Masalah di lapangan timbul karena satu pihak menuntut mode pluralitas (guru memahami kondisi siswa yang beragam) sedangkan pihak counterpart-nya (siswa) tidak diminta. Akhirnya, yang terjadi kedua belah pihak saling mengeluh. Siswa merasa tidak dipahami oleh guru.

Sebaliknya, di kalangan para guru muncul keluhan serupa. Guru merasa tidak dipahami oleh siswa. Rasanya tidak jarang kita mendengar keluhan guru, "Siswa sekarang tidak seperti siswa yang dulu. Dibandingkan siswa di masa lalu, siswa sekarang 'kurang ajar', 'tidak sopan', 'sulit diajar', dan sebagainya." Simak juga keluhan umum terhadap siswa, sebagaimana nampak pada Gambar 1.

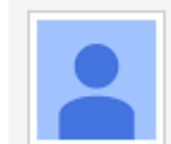

Wintolo Dewangga

21 Nov 2014 18:28:05 WIB

Ini akibat kesalahan orangtua juga, anak didik sekarang dimanja, dimarahi dikit sama guru lapor HAM..akhirnya mentalnya begini, gurupun akhirnya serba salah

+D Beri Tanggapan . Laporkan . IS Suka

Gambar 1: Keluhan terhadap siswa dan orangtuanya (Sumber: http://news.detik.com/read/2014/11/14/180950/2748891/10/terlibat-tawuran-20-siswasma-109-dikeluarkan-pihak-sekolah)

Mencermati komentar di atas, kalau menggunakan terminologi Mochtar Lubis tentang ciri manusia Indonesia (feodalistik), mungkin dapat dibahasakan: "Feodalisme guru' kini bergeser menjadi 'feodalisme siswa"'. Sinisme dan "kekacauan" ini, menurut hemat saya, tidak dapat diselesaikan secara memadai baik dengan intensifikasi TCL atau pun intensifikasi SCL. Mengapa? Karena persoalannya terletak pada aktivitas dan 
Abraham, J. (2015). Lupakanlah student centered learning. In: H. Panggabean, A. Supratiknya, \& J. S. A. Utama (Eds.), Revolusi mental: Makna dan realisasi (pp. 129-136). Jakarta: Himpunan Psikologi Indonesia.

interaksi. Kita seringkali mengatribusikan lokus penyebab masalah dalam dunia pendidikan ada pada guru (sehingga kita menafikan TCL) atau pada murid (sehingga kita menafikan SCL). Tentu saja, baik pada TCL maupun SCL, unsur aktivitas dan interaksi ada di dalamnya, namun bukan fitur natural melainkan hanya menjadi instrumen menuju koordinat pusat (center), yaitu guru-atau-siswa. Mungkin saja memang ada masalah pada kepribadian, kompetensi, dan keterampilan lembut (soft skill) dari guru maupun siswa. Namun demikian, pemahaman kita tidak akan utuh jika tidak meneropong aktivitas interaksional yang terjadi antara guru dan siswa serta sistem sekolah. Dengan perkataan lain, jika ingin melakukan penelitian yang lebih serius, lakukanlah penelitian dengan unit analisis ini.

\section{Team-centered Learning}

Hal yang sedang saya bicarakan dalam paragraf terakhir di atas saya sebut sebagai Team-centered Learning (MCL). Saya berpendapat, MCL adalah model pembelajaran yang tepat dan matang untuk saat ini. Saya akan menjelaskannya dengan menggunakan perspektif psikologi perkembangan yang sederhana.

Mengikuti alur psikologi perkembangan, TCL merupakan model pembelajaran yang mengandaikan siswa berada fase "kanak-kanak". Siswa adalah kertas putih yang "ditulisi” oleh gurunya. Ini pun ada syaratnya. Anak-anak diandaikan memenuhi syarat dan kapasitas untuk "ditulisi”. Sebagaimana pada fase perkembangan kanak-kanak, diandaikan manusia kecil itu tidak berdaya. Anak dituntut untuk mengerti kemauan orangtua. Orangtua (analogi guru) lah yang dianggap paling mengerti hal-hal yang terbaik untuk si anak (analogi siswa). Patut diingat juga bahwa tidak ada orangtua yang memiliki intensi sadar untuk "mencelakakan" anaknya sendiri. Kita ingin mengatakan bahwa TCL mengandung kebaikannya sendiri.

SCL dalam alur perkembangan ini analog dengan fase "remaja". Pembelajaran berpusat pada siswa. Sekelompok mahasiswa membuat video di Youtube (https://www.youtube.com/watch?v=MxFN1OXAP94) yang kiranya tepat menggambarkan dinamika yang terjadi pada model pembelajaran ini: "Karena Remaja Ingin Dimengerti'. Preferensi dan gaya belajar dari pelajar menjadi pusat perhatian. Guru merupakan fasilitator atau moderator. Segenap perangkat keras dan lembut diadakan 
Abraham, J. (2015). Lupakanlah student centered learning. In: H. Panggabean, A. Supratiknya, \& J. S. A. Utama (Eds.), Revolusi mental: Makna dan realisasi (pp. 129-136). Jakarta: Himpunan Psikologi Indonesia.

untuk pelajar agar pelajar mampu mengkonstruksikan pengetahuannya sendiri. SCL pun sesungguhnya mengandung kebaikannya sendiri.

Nah, kini saatnya kita memasuki model pembelajaran yang lebih matang! Analoginya dalam alur perkembangan adalah fase "dewasa". Setelah "orangtua ingin dimengerti oleh (dan mendefinisikan apa saja dari) anak" (TCL) dan "remaja ingin dimengerti oleh orangtua" (SCL), tibalah saatnya "anak dan orangtua berusaha untuk saling mengerti”. Asumsinya adalah bahwa terdapat kebenaran dalam kedua model pembelajaran sebelumnya. Apakah itu? Pertama, siswa menginginkan kegiatan belajar yang bermakna dan menekankan pelibatan dirinya (SCL). Kedua, guru juga ingin bereksperimen dengan beragam isi, teknik, dan praktik untuk mengaktualisasikan pembelajaran versinya. Kumulasi pengetahuan dan kebijaksanaan guru tidaklah mungkin tidak ada artinya. Dengan melihat kebenaran-kebenaran ini, refleksi dan pemecahan masalah bersama lalu menjadi aktivitas kunci yang perlu dikembangkan.

Kita sering mendengar bahwa ada di antara guru-guru kita yang pendidikannya tinggi, bahkan pernah belajar di luar negeri, namun dicap "tidak bisa mengajar" oleh siswanya. Mendengar hal ini, jika menggunakan paradigma Team-centered Learning, maka kita harus menelaah bagaimana interaksi berlangsung. Hal yang menarik dalam interaksi ini adalah bahwa "Siswa dapat 'membelajarkan' gurunya dalam proses interaksional" (Konteks 1). Bukanlah hal ini juga yang sering kita dengar dari para guru dan dosen? "Saya tidak hanya mengajar dari para (maha)siswa, tetapi juga belajar dari mereka". Yang kebanyakan terjadi selama ini jika kasus serupa itu terjadi adalah "Siswa 'meninggalkan' gurunya” (Konteks 2). Saya cukup yakin bahwa guru yang dicap "tidak bisa mengajar" itu jika "ditaruh" (berada) dalam dua konteks yang berbeda, akan menghasilkan outcome belajar yang berbeda bagi semua. Besar kemungkinan "mutiara" si guru keluar dan menampakkan keindahannya, dan pada gilirannya berdampak pada siswa, pada Konteks 1; dan "mutiara tertutupi lumpur", dan semua (di)-“kalah"-(kan), pada Konteks 2.

Dalam teori komunikasi mutakhir dikatakan bahwa makna terdapat dalam interaksi (yang diupayakan terus-menerus). Makna bukan terdapat pada diri komunikator, bukan juga eksis dalam diri komunikan. Selanjutnya, dalam teori kecerdasan yang menganut konstruksionisme sosial ini, inteligensi bukan terdapat pada 
Abraham, J. (2015). Lupakanlah student centered learning. In: H. Panggabean, A. Supratiknya, \& J. S. A. Utama (Eds.), Revolusi mental: Makna dan realisasi (pp. 129-136). Jakarta: Himpunan Psikologi Indonesia.

(otak) person melainkan terdapat pada jejaring sosial. Apa artinya? Sudah saatnya kita tidak lagi menaruh "pusat" pembelajaran pada guru atau pun siswa. Pusat pembelajaran adalah aktivitas menjadi tim ("teaming") dan tim itu sendiri. Sebagaimana sebuah tim sepakbola (atau tim pertunjukan teater), setiap anggota perlu menyadari bahwa dirinya adalah anggota sebuah tim. Kegagalan atau keberhasilan merupakan proses interaksi interdependensional; jadi tidak mudah untuk meletakkan "beban" kesalahan, mengkambinghitamkan salah satu pihak atas suatu kegagalan pembelajaran. Apabila menerapkan paradigma pelayanan, tidak ada yang semata-mata melayani dan tidak ada yang semata-mata dilayani. Semua anggota tim (berusaha, dengan sungguh) saling melayani, karena pusatnya adalah tim. Namun demikian, hasil dan kebanggaannya dapat dipetik oleh siapapun anggota tim.

\section{Sintesis}

Iwan Pranoto, Guru Besar Matematika pada Institut Teknologi Bandung (https://groups.google.com/forum/\#!msg/bn-indonesia/RT83dzZBH5c/0XVJ8ovLbnwJ), berargumen di Kompas baru-baru ini (24 November 2014) pada kolom Opini:

"Beberapa edukator menunjuk masalah pengajaran sebagai penyebabnya. Bagi yang rutin mendatangi dan mengamati pengajaran di persekolahan, memang umumnya terlihat murid mendengar pasif dan kurang aktif membangun pemahaman di kelas. Keterampilan mengajar mungkin saja penyebabnya. Namun, ada kemungkinan rendahnya keterampilan mengajar justru merupakan dampak ketimbang penyebab masalah. .... Seberapa pun pahamnya seseorang pada metode mengajar, jika dia tidak memahami makna pembagian $1 / 3: 2 / 5$, pengajaran matematikanya akan menjadi sebuah ceramah. Dia akan menuangkan pengetahuan mutlaknya ke benak para murid. Murid yang seperti busa penyerap akan dipaksa mematuhi prosedur cara menghitung tanpa paham alasan di balik perhitungan itu.... Sebaliknya, jika seorang guru memahami keilmuannya serta bergairah mengajar, tentunya dia akan termotivasi mempelajari teori belajar dan metode mengajar. Dia akan bersemangat meningkatkan pemahaman pedagoginya. Terlebih, berlatih diri dalam metode mengajar menjadi masuk akal karena dia ingin mengajak muridnya belajar sekaligus menikmati kasmaran belajar yang dialaminya. Syarat utama, guru harus memahami keilmuannya. Ada dua area yang perlu dibenahi. Pertama, pada program penyiapan guru perlu dikembangkan sebuah kurikulum baru yang memberikan porsi besar pada pemahaman keilmuan. Calon guru mutlak perlu 
Abraham, J. (2015). Lupakanlah student centered learning. In: H. Panggabean, A. Supratiknya, \& J. S. A. Utama (Eds.), Revolusi mental: Makna dan realisasi (pp. 129-136). Jakarta: Himpunan Psikologi Indonesia.

mengalami kasmaran belajar keilmuannya. Yang akan mengajar sejarah harus pernah merasakan nikmatnya kasmaran menyelami sejarah dan menelitinya.... "

Dengan cara pandang yang telah saya kemukakan di atas, saya dapat mengaplikasikannya guna menganalisis pernyataan Iwan Pranoto di atas. Sebenarnya hal yang disampaikan Iwan merupakan perdebatan antara TCL dan SCL. Pada TCL, bukankah guru harus memahami keilmuannya? Pada SCL, bukankah guru sekarang "dibombardir" dengan segala macam "teknik mengajar" (dan diminta untuk mengikuti ragam pelatihannya!) yang diklaim berorientasi pada siswa?

Menggunakan paradigma dialektika dari Immanuel Kant, saya mengandaikan, jika Teacher-centered learning (TCL) merupakan "tesis" dan Student-centered learning (SCL) merupakan "anti-tesis", maka Team-centered learning (MCL) merupakan "sintesis"-nya. Sintesis berarti mengambil kebaikan, keunggulan dari tesis dan anti-tesis kemudian mengelaborasinya menjadi sebuah "tesis" baru (ialah sebuah gestalt, bukan sekadar penjumlahan, melainkan totalitas konfigurasi baru) yang lebih memadai untuk menjawab kebutuhan dunia pendidikan saat sekarang yang sedang "galau”. Generalisasi dari gagasan MCL ini adalah, misalnya, "teaming" dapat dilakukan antara sekolah dan masyarakat, antara warga dan pemerintah, antara pemimpin dan pengikut.

Di saat dunia psikologi industri dan organisasi sudah pesat dengan riset-riset mengenai "team learning" dalam learning organization, dunia (psikologi) pendidikan masih berkutat dengan "student-centered learning" bahkan mengklaim, mungkin secara "ilusif", bahwa team-centered learning merupakan bagian total darinya. Saya menandaskan, mulai sekarang, "Lupakanlah" Student-centered Learning.

Kita sungguh memerlukan banyak riset, kajian, dan praktik untuk mendudukkan gagasan Team-centered learning pada hakikat dan tempatnya yang persis. Inilah yang menurut hemat saya merupakan salah satu revolusi mental yang penting dalam dunia pendidikan kita. 
Juneman Abraham, dosen tetap pada Jurusan Psikologi, Fakultas Humaniora, Universitas Bina Nusantara. Alumnus program studi S1 Psikologi Universitas Persada Indonesia YAI dan program Magister Sains Psikologi Sosial Universitas Indonesia. Memperoleh sertifikasi internasional Certified Webmaster Professional (CWP) dari World Organization of Webmasters (2001), saat ini merupakan Ketua Kompartemen Keorganisasian dan Keanggotaan, Pengurus Pusat HIMPSI. Aktif terlibat di beragam organisasi serta kegiatan terkait penerbitan dan penulisan buku. Menjadi anggota Sidang Penyunting Jurnal Ilmiah Psikologi PSIKOBUANA Universitas Mercu Buana Jakarta (2008-2011), Jurnal Kesehatan Jiwa Indonesia ATARAXIS (2007), Indonesian Journal of Legal and Forensic Sciences/IJLFS (2008), Jurnal Psikologi Ulayat/Indonesian Journal of Indigenous Psychology (2012-2014), dan Ketua Sidang Penyunting Jurnal Ilmiah Psikologi Industri dan Organisasi/ JPIO (sejak 2012). Menulis buku hasil penelitian Psychology of Fashion (LKIS, 2010). Menyunting buku Program Keluarga Harapan di Indonesia: Dampak Pada Rumah Tangga Sangat Miskin di Tujuh Provinsi (Pusat Penelitian dan Pengembangan Kesejahteraan Sosial/ P3KS Press, Jakarta, ISBN 9786028427708,2012$)$ serta Isu Etik Dalam Penelitian di Bidang Kesehatan (AIFI \& Universitas YARSI, ISBN 9786021420805,2013$)$. Mengikuti pelatihan Intercultural Rhetoric (diselenggarakan oleh Psychology Department-UNIKA Atma Jaya Jakarta \& Institut fuer Kommunikation and Interkulturelle Kompetenz, Hochschule fuer Technik Rapperswil, Switzerland, 2014) dan Male Counseling/Konseling Perubahan Perilaku Untuk Laki-laki (diselenggarakan oleh PULIH Foundation \& RutgersWPF, 2014). Dapat dihubungi melalui email juneman@socialpsychologist.org. 
